\title{
Interplanting Wheat Is Not an Effective Postplant Management Tactic for Criconemella xenoplax in Peach Production
}

\author{
A. P. Nyczepir, Research Nematologist, U.S. Department of Agriculture, ARS, Southeastern Fruit and Tree Nut Re- \\ search Laboratory, 21 Dunbar Road, Byron, GA 31008; P. F. Bertrand, Professor, Extension Plant Pathologist, \\ University of Georgia, Tifton 31793; M. L. Parker, Associate Professor, Department of Horticultural Science, and \\ J. R. Meyer, Professor, Department of Entomology, North Carolina State University, Raleigh 27695; and E. I. \\ Zehr, Professor, Department of Plant Pathology and Physiology, Clemson University, SC 29634
}

\begin{abstract}
Nyczepir, A. P., Bertrand, P. F., Parker, M. L., Meyer, J. R., and Zehr, E. I. 1998. Interplanting wheat is not an effective postplant management tactic for Criconemella xenoplax in peach production. Plant Dis. 82:573-577.

In two orchard experiments, interplanting wheat (Triticum aestivum cv. Stacy) around either newly planted or 4-year-old well-established peach trees did not suppress $(P \leq 0.05)$ the population density of the ring nematode, Criconemella xenoplax, after 3 years. Furthermore, interplanting wheat around newly planted trees reduced tree growth, perhaps the result of competition for water and (or) nutrients. Wheat root exudate was not as attractive to C. xenoplax as peach root exudate, but wheat root exudate did not repel the nematode either. Stacy wheat appeared to be more beneficial as a preplant rather than as a postplant ground cover management tool for suppressing the population density of C. xenoplax.
\end{abstract}

Additional keywords: cultural control, Prunus persica, short life

Commercial peach (Prunus persica (L.) Batsch) production in the United States was at its peak in the early 1900s, with over 80 million trees in production (17). By 1993, it was estimated that there were just over 19 million trees (18). Two important factors contributing to the decline in the Southeast have been the lack of new orchard sites and the peach tree short life complex (PTSL) (2). Peach tree short life is associated with a complex of factors, some of which increase over time during peach production. Reuse of old orchard sites is commonly known to increase the incidence of PTSL (13). The ring nematode, Criconemella xenoplax (Raski) Luc \& Raski (=Mesocriconema xenoplax (Raski) Loof \& de Grisse), appears to be the major contributing cause of disease. It makes trees more susceptible to cold injury and (or) bacterial canker, Pseudomonas syringae pv. syringae, the causal agents of sudden collapse of trees associated with PTSL $(2,9)$. In the past, as orchards became unproductive, growers could relocate to a site where peach trees had not grown

Corresponding author: A. P. Nyczepir E-mail: A03ANYCZEPIR@ATTMAIL.COM

Accepted for publication 10 February 1998.

Publication no. D-1998-0312-02R

This article is in the public domain and not copyrightable. It may be freely reprinted with customary crediting of the source. The American Phytopathological Society, 1998. previously. However, growers now are faced with the problem of finding suitable sites with no history of PTSL or peach production. Management of C. xenoplax is essential for minimizing losses in peach to the PTSL syndrome.

In recent years, research on nematode management has been concentrated on alternatives to conventional nematicide applications. Emphasis on nonchemical control is the result of three factors: (i) suspended registration of most highly efficacious preplant fumigant nematicides, such as 1,2-dibromo-3-chloropropane (DBCP) (10); (ii) the expense and difficulty of achieving a long-term nematode population density reduction with a single preplant fumigant application; and (iii) the social need to move away from chemical pest control wherever possible. Fenamiphos, the only available postplant nematicide, is not widely used by growers due to high cost and inconsistent results $(4,16)$.

Progress in the search for nonchemical control strategies for $C$. xenoplax and the PTSL complex has been made in recent years. Increased scion survival on an improved rootstock more tolerant to PTSL than the standard Lovell rootstock (14) and suppression of $C$. xenoplax with preplant wheat-sorghum rotation $(11,12)$ are two areas in which progress has occurred. In greenhouse and field studies, wheat (Triticum aestivum cv. Stacy) consistently reduced the population density of $C$. xenoplax over time. An important component in a postplant integrated nematode management strategy would be a ground cover that has the following characteristics: (i) suppresses C. xenoplax under established peach trees; (ii) does not compete excessively with the tree for water and nutrients; (iii) does not harbor orchard pests; and (iv) is easy to establish under orchard conditions. Nimblewill (Muhlenbergia schreberi J.F. Gmel.) was identified in North Carolina as a potential postplant ground cover for commercial peach orchards (8). However, this perennial grass was very difficult to establish in sandy soils in warmer peach production areas such as South Carolina (15).

The objectives of this study were as follows: (i) to evaluate the potential of Stacy wheat as a postplant management strategy in suppressing the population density of $C$. xenoplax under newly established and 4-year-old peach trees; (ii) to determine the competitive effect of wheat on young tree growth during orchard establishment; and (iii) to evaluate the attractiveness of wheat and peach root extracts to the ring nematode.

\section{MATERIALS AND METHODS}

Orchard trial 1. The experiment was initiated in December 1990 in a 4-year-old commercial peach orchard near Fort Valley, Georgia. The orchard was planted to cv. Juneprince on Nemaguard rootstock at a tree spacing of $4.9 \times 6.1 \mathrm{~m}$ in a sandy soil $(90 \%$ sand, $2 \%$ silt, $8 \%$ clay; $\mathrm{pH}$ 5.9; $2.41 \%$ organic matter) known to be infested with C. xenoplax.

Plots consisted of three postplant treatments, as follows: (i) winter wheat, replanted annually; (ii) fall-spring application of fenamiphos; and (iii) untreated perennial bare ground (conventional herbicide strip) (5), which served as the control. Treatments were established under the drip lines in a 1.5-m strip on both sides of the tree. Each plot had five trees, the outer two of which served as borders for the three center trees as the experimental unit. A border row of trees also paralleled the test rows on either side. Treatments were replicated eight times in randomized complete blocks.

All trees received annual applications of fertilizer (314 kg/ha, 19-19-19 N-P-K), 
insecticides, and herbicides as recommended by the Georgia Cooperative Extension Service $(4,5)$. All rates were according to the schedule outlined for bearing trees (4).

The test site within the wheat plots was shallow-disked $(10.0 \mathrm{~cm})$ before Stacy wheat was planted at a seeding rate of 135 $\mathrm{kg} / \mathrm{ha}$ with a Vicon Super Flow fertilizer spreader (Vicon Southeast, Inc., Trussville, AL) with a band spreading spout on 19 December 1990, 9 December 1991, and 14 December 1992. Wheat plots were topdressed with $\mathrm{N}$ as ammonium nitrate (34$0-0)$ at $67 \mathrm{~kg} / \mathrm{ha}$ in the spring each year. The wheat was allowed to head out and mature in 1992 and 1993 but was removed prematurely on 2 April 1991, when paraquat $(0.78 \mathrm{~kg}$ a.i./ha) was applied to the wheat in all plots. Otherwise, no herbicides were applied to the wheat plots until after maturity. Wheat stalks were mowed, and the stubble was allowed to remain on the soil surface throughout the summer months until the soil was disked in the fall each year. Weeds in all plots were controlled with oryzalin $(4.5 \mathrm{~kg}$ a.i./ha), paraquat, or glyphosphate (4.49 kg a.i./ha) as needed.

Fenamiphos (Nemacur 3EC) was applied (11.2 kg a.i./ha) in a $1.5-\mathrm{m}$ band on both sides of each treated tree on 18 April and 30 October 1991 with a bicycle boomsprayer applicator. Fenamiphos was incorporated with $3.8 \mathrm{~cm}$ of natural rainfall and shallow-disking (5 to $7 \mathrm{~cm}$ ), respectively. On 30 April and 16 October 1992, and 27 April 1993, fenamiphos was applied with a tractor-driven Walkover Fieldmaster applicator (Walkover Sprayers, Ltd., Cambridge, England) and incorporated by shallow-disking. Initial population density (Pi) of C. xenoplax was determined on 21 January 1991 from eight soil cores $(2.5 \mathrm{~cm}$ diameter $\times 30 \mathrm{~cm}$ deep) collected from every second tree within each replicate throughout the test site. C. xenoplax population densities were determined also on 18 October 1991, 25 June and 14 October 1992, and 7 July and 15 September 1993 from two soil cores collected within the drip line of each of three test trees of each experimental unit. The six soil cores were composited, and nematodes were extracted from a $100 \mathrm{~cm}^{3}$ subsample with a semiautomatic elutriator (3) and centrifugal flotation (6).

Orchard trial 2. The experiment was initiated in November 1991 at the Sandhills Research Station, Jackson Springs, North Carolina. The study was conducted on a Candor soil $(93.5 \%$ sand, $5.3 \%$ silt, $1.2 \%$ clay; $\mathrm{pH} 5.9 ; \leq 1 \%$ organic matter) with a previous history of PTSL. Peach trees were grown on this site from 1980 until their removal in 1990 following severe tree losses $(>60 \%)$ due to PTSL.

Plots consisted of three ground cover management systems that were maintained over the entire orchard floor, including: (i) perennial bare ground; (ii) Stacy winter wheat replanted annually; and (iii) natural vegetation (weeds), which served as the control. Ground cover treatments were established in blocks measuring $30.8 \times$ $30.8 \mathrm{~m}$. Within each block, four rows of six trees of cv. Legend on Lovell rootstock were planted on a tree spacing of $4.3 \times 6.2$ $\mathrm{m}$ in February 1992. On 14 October 1991, before planting, the soil for three trees in each plot was preplant fumigated with 1,3dichloropropene (1,3-D) (262 liters/ha). Treatments were replicated three times in a randomized complete block with a splitplot design. The whole-plot factor was the ground cover treatment, with soil fumigation as the subplot factor. The middle tree in each subplot served as the test tree, with the outer tree on either side serving as borders.

All peach trees in each treatment received identical applications of fertilizer each year. In 1992 and 1993, trees received $11 \mathrm{~kg} / \mathrm{ha}(17-17-17 \mathrm{~N}-\mathrm{P}-\mathrm{K})$ and $60 \mathrm{~kg} / \mathrm{ha}$ (20-20-20 N-P-K), respectively. Trees received $\mathrm{N}$ and $\mathrm{K}$ at $77 \mathrm{~kg} / \mathrm{ha}(20-0-20)$ in 1994.

Stacy wheat was planted $(133 \mathrm{~kg} / \mathrm{ha})$ with a 14-row drill with $17.8 \mathrm{~cm}$ between rows in September 1991 and in October 1992 and 1993. All wheat plots received the same fertilizer at the same time and rate as the peach trees in 1992 and 1993. Wheat stubble was mowed and left in the field after maturity. If necessary, vegetation

Table 1. Population densities of Criconemella xenoplax on peach, as influenced by three management strategies, in field plots in Fort Valley, Georgia ${ }^{w}$

\begin{tabular}{|c|c|c|c|c|c|c|}
\hline \multirow[b]{2}{*}{ Treatment } & \multirow[b]{2}{*}{ Rate } & \multicolumn{5}{|c|}{ C. xenoplax per $100 \mathrm{~cm}^{3}$ of soil ${ }^{\mathrm{x}}$} \\
\hline & & $\begin{array}{c}18 \text { Oct } \\
1991\end{array}$ & $\begin{array}{l}25 \text { June } \\
1992\end{array}$ & $\begin{array}{c}14 \text { Oct } \\
1992\end{array}$ & $\begin{array}{c}7 \text { July } \\
1993\end{array}$ & $\begin{array}{c}15 \text { Sept } \\
1993\end{array}$ \\
\hline Wheat & $135 \mathrm{~kg} / \mathrm{ha}$ & $227 \mathrm{a}^{\mathrm{y}}$ & $519 \mathrm{a}$ & 489 a & $120 \mathrm{a}$ & $143 \mathrm{a}$ \\
\hline Bare ground & & $204 \mathrm{a}$ & $551 \mathrm{a}$ & $332 \mathrm{a}$ & $146 \mathrm{a}$ & $73 \mathrm{a}$ \\
\hline Fenamiphos $^{z}$ & $11.2 \mathrm{~kg}$ a.i.//ha & $32 \mathrm{~b}$ & $343 \mathrm{a}$ & $615 \mathrm{a}$ & $197 \mathrm{a}$ & $113 \mathrm{a}$ \\
\hline
\end{tabular}

${ }^{\mathrm{w}}$ Data are means of eight replications per treatment.

${ }^{x}$ Mean preplant soil population density of C. xenoplax (January 1991) was 381 adults and juveniles per $100 \mathrm{~cm}^{3}$ of soil.

${ }^{y}$ Nematode means followed by the same letter are not different $(P \leq 0.05)$ according to Fisher's least significant difference. Actual data are presented, but data were transformed by $\log _{10}(x+1)$ before analysis.

${ }^{\mathrm{z}}$ Application dates: 18 April and 30 October 1991, 30 April and 16 October 1992, and 27 April 1993. was eliminated with paraquat $(1.14 \mathrm{~kg}$ a.i./ha) in the wheat plots before wheat was planted. Weeds in the bare ground treatment plots were controlled with the herbicides 2,4-D (1.1 kg a.i./ha), paraquat, simazine $(0.57 \mathrm{~kg}$ a.i./ha), or oryzalin $(2.27$ $\mathrm{kg}$ a.i./ha) only as necessary.

The population density of $C$. xenoplax was determined on 13 February, 15 April, 23 July, 20 August, 17 September, 22 October, and 18 December 1992, and on 19 February, 22 April, 28 July, 19 August, 9 September, 29 October, and 17 December 1993, from four soil cores $(2.5 \mathrm{~cm}$ diameter $\times 15 \mathrm{~cm}$ deep) collected 30 to $46 \mathrm{~cm}$ from the tree trunk of the test tree. The four soil cores were composited by subplot within each replicate, and the nematodes were extracted from a $100 \mathrm{~cm}^{3}$ subsample as described for the first orchard trial.

Peach tree growth of all trees in the planting was evaluated on 15 April 1992, 11 February 1993, and 3 February 1994. Trunk diameter at $30 \mathrm{~cm}$ above the graft union was measured twice on each tree, with measurements taken perpendicular to each other. Trunk cross-sectional area (TCSA) $\left(\mathrm{cm}^{2}\right)$ was then calculated based on average trunk diameter.

Evaluation of root exudates. Exudates were acquired by using a procedure modified for peach and wheat tissues (1). Briefly, exudates from Nemaguard peach and Stacy wheat roots were obtained from $4.6 \mathrm{~g}$ fresh weight root tissue placed in separate 250-ml Erlenmeyer flasks containing $150 \mathrm{ml}$ of sterile distilled water. The flasks were wrapped in aluminum foil, and the roots were allowed to soak in darkness for 17 to $24 \mathrm{~h}$ at $25^{\circ} \mathrm{C}$. The exudates were filtered (Whatman no. 2 filter paper), freeze-dried, and stored at $-12^{\circ} \mathrm{C}$. The dried filtrates were resuspended in 10 $\mathrm{ml}$ of sterile distilled water before use in the nematode attractiveness assays.

Root exudate attractiveness to $C$. xenoplax was observed on an $85 \times 25 \mathrm{~mm}$ strip of $1.5 \%$ agar in the bottom of a $100 \times 15$ $\mathrm{mm}$ plastic petri dish. A 10 -mm-diameter well was made at either end of the strip with a no. 5 cork borer. Approximately 200 $\mu \mathrm{l}$ of test solution was pipetted into each well. Seven to 10 mobile $C$. xenoplax were transferred to a 5- $\mu$ ldrop of water in the center of the agar strip and observed for movement toward or away from the test solutions.

Root exudates or sterile distilled water were placed in the wells in the following combinations: (i) peach and water; (ii) wheat and water; (iii) peach and wheat; and (iv) water and water. Attractiveness of root exudates to C. xenoplax was measured as the percentage of nematodes selecting one or the other choice, weighted by the total distance $(\mathrm{mm})$ these nematodes moved after 17 to $20 \mathrm{~h}$ in the dark at $25^{\circ} \mathrm{C}$. Treatment combinations were arranged in randomized complete blocks and replicated four times, and the test was repeated one 
time. Modifications in the second test included placement of a $56 \times 8 \mathrm{~mm}$ strip of agar in the bottom of a $60 \times 15 \mathrm{~mm}$ petri dish and substitution of the well at either end of the agar strip with a 5-mm-diameter paper disk (Whatman no. 2 filter paper). One hundred microliters of test solution was pipetted onto the paper disk. A disk containing the root exudate or water was placed at either end of the agar strip before the nematodes were placed on the agar strip. All dishes were placed on a Bellco Roller Drum (Bellco Glass, Inc., Vineland, $\mathrm{NJ})$ and allowed to rotate $(0.5 \mathrm{rpm})$ until the nematodes were assessed for attractiveness to the test solutions.

Statistics. Nematode data were transformed to $\log _{10}(x+1)$ values and subjected to analysis of variance with the general linear models (GLM) procedure of SAS (SAS Institute, Cary, NC). Analysis of variance was also performed to determine treatment effect on trunk cross-sectional area (TCSA). For orchard test 1, means were compared according to Fisher's protected least significant difference (LSD) test following a significant $F$ test. For orchard test 2, nematode and TCSA means of main effects were compared according to Fisher's protected LSD test following a significant $F$ test. Only main effect values for ground cover and fumigation are reported, because the interaction between ground cover and fumigation was not significant. Actual numerical nematode data were used for table presentation in orchard tests 1 and 2 . For the root exudate study, a mobility rating $(\mathrm{Z})$ was calculated as the product of the proportion of $C$. xenoplax, which selected a given stimulus and the total distance $(\mathrm{mm})$ that the $C$. xenoplax moved. This result $(\mathrm{Z})$ was analyzed as a series of paired comparisons to test the equality of competing stimuli (peach versus water, peach versus wheat, wheat versus water, and water versus water). Further comparisons of the data were performed to test the equality of two stimuli in the presence of a third (common) stimulus (i.e., wheat versus water in the presence of peach and peach versus water in the presence of wheat). All analyses were done with the $t$ test procedure of SAS. Only significant differences $(P \leq$ $0.05)$ will be discussed unless stated otherwise.

\section{RESULTS AND DISCUSSION}

Orchard trial 1. The mean initial population density of $C$. xenoplax for eight replications was $381 / 100 \mathrm{~cm}^{3}$ of soil (range 135 to 735 ), which indicated that the ring nematode was present throughout the test site. In October 1991, fewer $(P \leq 0.05) C$. xenoplax were detected in the root zone of trees treated with fenamiphos than in the wheat or untreated bare ground (Table 1). No differences in the population density of C. xenoplax were detected between the wheat and the untreated bare ground treatments, or among any of the treatments in the 1992 and 1993 sampling periods. One explanation for nematode control in the fenamiphos plot on 18 October 1991, but not on the last four sampling dates, was the lack of rainfall following nematicide application. According to Ritchie (16), rainfall within a few days of application and incorporation can improve fenamiphos activity.
Moreover, fenamiphos has a history of poor nemastatic activity in dry soils (K. Noegel, personal communication). In our test, the only application date with more than $2.5 \mathrm{~cm}$ of rainfall within $72 \mathrm{~h}$ of incorporation was on 18 April 1991. Rainfall amounts ranged from 0.03 to $0.08 \mathrm{~cm}$ within a 7-day period after incorporation on the later treatment dates. Furthermore, dry weather also prevailed 7 days before application; recorded rainfall amounts were $0,0,0.25$, and $0.23 \mathrm{~cm}$, respectively.

Orchard trial 2. The mean population density of C. xenoplax was $150 / 100 \mathrm{~cm}^{3}$ of soil (range 100 to 200) just before the old orchard was removed in 1990. However, the Pi of C. xenoplax at planting in February 1992 was $24 / 100 \mathrm{~cm}^{3}$ soil (range 1 to 86). Two explanations for this decline in nematode population density could be: (i) the lack of a sufficient food source after the older peach trees were removed, and (ii) the disturbance of the soil ecosystem resulting from the removal of the older roots and in preparation for the new orchard planting. Such disturbance of the soil ecosystem may result in nematode mortality due to rapid desiccation, because the majority of the nematodes would be in the rhizosphere of the old peach roots. An

Table 3. Effect of three ground cover systems and soil fumigation on peach trunk cross-sectional area of cv. Legend/Lovell in field plots in Jackson Springs, North Carolina, 1992 to $1994^{\mathrm{y}}$

\begin{tabular}{lccc}
\hline & \multicolumn{3}{c}{ Trunk cross-section area $\left.\mathbf{( c m}^{2}\right)$} \\
\cline { 2 - 4 } Treatment & 15 Apr 1992 & 11 Feb 1993 & 3 Feb 1994 \\
\hline Ground cover ${ }^{\mathrm{z}}$ & & & \\
Wheat & $0.25 \mathrm{~b}$ & $1.98 \mathrm{~b}$ & $6.20 \mathrm{~b}$ \\
Weeds & $0.33 \mathrm{a}$ & $2.07 \mathrm{~b}$ & $5.60 \mathrm{~b}$ \\
Bare ground & $0.30 \mathrm{ab}$ & $3.84 \mathrm{a}$ & $18.10 \mathrm{a}$ \\
Fumigation & & & \\
Untreated check & $0.28 \mathrm{a}$ & $2.54 \mathrm{a}$ & $8.5 \mathrm{a}$ \\
1,3-D & $0.30 \mathrm{a}$ & $2.72 \mathrm{a}$ & $11.4 \mathrm{~b}$ \\
\hline
\end{tabular}

${ }^{y}$ Data are means of three replications per ground cover treatment, each split for preplant fumigation. Data from fumigated and nonfumigated ground cover plots were combined because the interaction of ground cover and fumigation was not significant.

${ }^{\mathrm{z}}$ Means within a main effect and column followed by the same letter are not significantly different by Fisher's least significant difference at $P \leq 0.05$. Application date of $1,3-\mathrm{D}$ was on 14 October 1991.

Table 2. Populations of Criconemella xenoplax on peach, as influenced by three ground cover systems and soil fumigation, in field plots in Jackson Springs, North Carolinaw

\begin{tabular}{|c|c|c|c|c|c|c|c|c|c|c|c|c|c|c|}
\hline \multirow[b]{3}{*}{ Treatment } & \multicolumn{14}{|c|}{ C. xenoplax per $100 \mathrm{~cm}^{3}$ of soil } \\
\hline & \multicolumn{7}{|c|}{1992} & \multicolumn{7}{|c|}{1993} \\
\hline & 13 Feb & 15 Apr & $23 \mathrm{Jul}$ & 20 Aug & 17 Sep & 22 Oct & 18 Dec & 19 Feb & $22 \mathrm{Apr}$ & $28 \mathrm{Jul}$ & 19 Aug & 9 Sep & 29 Oct & 17 Dec \\
\hline \multicolumn{15}{|l|}{ Ground cover ${ }^{y}$} \\
\hline Weeds & 11 & 7 & 18 & 12 & 2 & 18 & 2 & 20 & 66 & 47 & 125 & 146 & 74 & 79 \\
\hline Bare ground & 18 & 10 & 19 & 53 & 13 & 19 & 19 & 20 & 55 & 10 & 68 & 86 & 92 & 80 \\
\hline Wheat & 10 & 12 & 18 & 20 & 9 & 6 & 2 & 6 & 32 & 18 & 60 & 93 & 44 & 64 \\
\hline \multicolumn{15}{|l|}{ Fumigation ${ }^{z}$} \\
\hline Untreated check & $24 \mathrm{a}$ & $11 \mathrm{a}$ & $37 \mathrm{a}$ & $55 \mathrm{a}$ & $15 \mathrm{a}$ & $28 \mathrm{a}$ & $14 \mathrm{a}$ & $29 \mathrm{a}$ & $98 \mathrm{a}$ & $46 \mathrm{a}$ & $120 \mathrm{a}$ & $164 \mathrm{a}$ & $112 \mathrm{a}$ & $115 \mathrm{a}$ \\
\hline $1,3-\mathrm{D}$ & $2 \mathrm{~b}$ & $8 \mathrm{a}$ & $0 \mathrm{~b}$ & $1 \mathrm{~b}$ & $1 \mathrm{~b}$ & $1 \mathrm{~b}$ & $1 \mathrm{a}$ & $1 \mathrm{~b}$ & $4 \mathrm{~b}$ & $3 b$ & $48 \mathrm{a}$ & $53 \mathrm{a}$ & $28 \mathrm{a}$ & $28 \mathrm{a}$ \\
\hline
\end{tabular}

${ }^{\mathrm{w}}$ Data are means of three replications per ground cover treatment, each split for preplant fumigation. Data from fumigated and nonfumigated ground cover plots were combined because the interaction of ground cover and fumigation was not significant.

${ }^{x}$ Mean preplant soil population density of C. xenoplax (February 1992) was 24 adults and juveniles per $100 \mathrm{~cm}^{3}$ of soil.

${ }^{y}$ Data transformed by $\log _{10}(x+1)$ revealed significant differences $(P \leq 0.05)$ related to ground cover on 17 September 1992 and 29 October 1993 only. Each was significantly different from the other on 17 September, and wheat ground cover differed from weeds on 29 October.

${ }^{\mathrm{z}}$ Means within a main effect and column followed by the same letter are not significantly different by Fisher's least significant difference at $P \leq 0.05$. Actual data are presented, but data were transformed by $\log _{10}(x+1)$ before analysis. Application date of 1,3-D was 14 October 1991 . 
interaction between ground cover and fumigation treatments was detected on the September 1992 and October 1993 sampling dates. However, the interaction was not of concern because no pattern leading up to or after the sampling date within a given year or from year to year was evident. No effect of ground cover treatment on the population density of $C$. xenoplax in a newly established orchard was detected in 12 of 14 sampling dates during 1992 to 1993 (Table 2). On 17 September 1992, the nematode population density was greatest $(P \leq 0.05)$ in bare ground, intermediate in wheat, and lowest in the weedy plots. On 29 October 1993, however, populations in wheat plots were lower than those in the weedy plots.

Preplant fumigation with 1,3-D lowered $(P \leq 0.05)$ the population density of $C$. xenoplax compared with that in untreated soil on five of seven sampling dates (71\%) during the first year (1992). Twenty-two months after application (August 1993), the nematode population density had increased in the fumigated plots and did not differ from those in the untreated check; similar results were observed for subsequent sampling dates. Our results substantiate those of Zehr and Golden (20), who reported that managing $C$. xenoplax with a preplant fumigant (i.e., 1,3-D) was not effective beyond 2 years following initial treatment.

Differences in TCSA were detected among the ground cover treatments on all three sampling dates (Table 3). In 1992, approximately 2 months after the trees were planted, TCSA was lowest in trees in the wheat plots and greatest in those in the weedy check. Trees growing in bare ground did not differ in TCSA from those in the wheat or weedy plot treatments. In April, wheat plants were actively growing, and growth stage was advanced relative to the vegetative growth in the weedy plots. On subsequent sampling dates, trees

Table 4. Attractiveness of peach and wheat root exudates to Criconemella xenoplax ${ }^{x}$

\begin{tabular}{lcl}
\hline & \multicolumn{2}{c}{ Nematode mobility rating } \\
\cline { 2 - 3 } Treatment & Test 1 & Test 2 \\
\hline Peach & $32.95^{* * z}$ & 4.45 \\
vs. water & 0.25 & 0.04 \\
Wheat & $18.85^{+}$ & $3.25^{*}$ \\
vs. water & 0.30 & 0.53 \\
Peach & $23.33^{* *}$ & $5.20^{*}$ \\
vs. wheat & 2.00 & 0.58 \\
Water & 3.68 & 0.83 \\
vs. water & 10.90 & 0.53 \\
Water/peach & 0.25 & 0.04 \\
vs. wheat/peach & 2.00 & 0.58 \\
Water/wheat & $0.30^{* *}$ & $0.53^{*}$ \\
vs. peach/wheat & 23.33 & 5.20 \\
\hline
\end{tabular}

${ }^{\mathrm{x}}$ Data are means of four replications.

${ }^{y}$ Proportion of $C$. xenoplax selecting a given stimulus multiplied by total distance $(\mathrm{mm})$ these nematodes moved.

${ }^{\mathrm{z}}+, P<0.10, *, P \leq 0.05,{ }^{* *}, P \leq 0.01$ within a given test using paired $t$ tests. growing in bare ground were larger $(P \leq$ 0.05 ) than trees growing in either the wheat or weedy check plots (Table 3). Reduced tree growth in the wheat and weedy ground cover plots may result from: (i) competition for water and nutrients between the ground cover and the peach tree, as was shown for peach and common bermudagrass, Cynodon dactylon (L.) Pers., a major weed species in the Southeast (19), and possibly (ii) the response of the tree to alleopathic compounds released from wheat, known to inhibit growth of certain weed species (7). Wheat and weeds appeared to suppress tree growth at equivalent rates as vegetative growth became more established within the weedy plots over time, resulting in more competition between the trees and weeds.

Differences in tree growth in fumigated plots were not detected until 1994, when trees growing in 1,3-D treated soil were larger $(P \leq 0.05)$ than those in untreated soil (Table 4).

Evaluation of root exudates. Peach root exudate attracted a greater $(P \leq 0.01)$ number of $C$. xenoplax than water in test 1 and perhaps also in test 2 (Table 4). $C$. xenoplax also preferred wheat root exudate over water. However, when $C$. xenoplax was exposed to peach and wheat root exudates, a greater number of nematodes moved toward the peach. No difference in nematode attraction was detected between water and water. Further analysis to test the equality of stimuli in the presence of a common stimulus (i.e., water versus peach in the presence of wheat or water versus wheat in the presence of peach) showed that peach was a better stimulus than water in the presence of wheat; whereas wheat did not influence $C$. xenoplax over water in the presence of peach. The identities of the attractive and less-attractive compounds in peach and wheat were not investigated in this study.

Our field and laboratory results may partially explain why Stacy wheat did not suppress $C$. xenoplax when interplanted with peach. One explanation might be that wheat is a poor host to C. xenoplax and, when wheat is grown in the absence of peach roots, the nematode population will decline $(11,12)$. Furthermore, preplant wheat may be suppressing other plants that might support low populations of $C$. xenoplax. It is known that some wheat cultivars are capable of suppressing certain weed species under field conditions (7). Wheat root exudate is not repulsive to $C$. xenoplax, but it is less attractive to the nematode than peach root exudate. Additionally, wheat root exudate did not appear to disorient $C$. xenoplax in the presence of peach, which may help explain why the population density of $C$. xenoplax was not suppressed when wheat was interplanted with peach trees under orchard conditions. When wheat and peach are interplanted, the nematode is apparently capable of lo- cating its preferred food source (i.e., peach), continues to survive and reproduce, and does not appear to be affected by the less attractive food source (i.e., wheat). Our results also demonstrated that interplanting wheat within a newly established orchard inhibited young tree growth over a 3 -year period. Interplanting wheat directly under young peach trees does not appear to be a sound management practice from a nematode or cultural management standpoint. In summary, Stacy wheat appears to be more beneficial as a preplant rather than as a postplant ground cover management tool for suppressing the population density of C. xenoplax.

\section{ACKNOWLEDGMENTS}

We thank Ray Adams for technical assistance and Al Pearson for providing land on which to conduct the field experiment in Georgia. The research in North Carolina was partially funded by a grant from the Southern Region Integrated Pest Management Grant Program.

\section{LITERATURE CITED}

1. Bird, A. F. 1959. The attractiveness of roots to the plant parasitic nematodes Meloidogyne javanica and $M$. hapla. Nematologica 4:322335.

2. Brittain, J. A., and Miller, R. W. 1978. Managing peach tree short life in the Southeast. Clemson Univ. Ext. Bull. 585.

3. Byrd, D. W., Jr., Barker, K. R., Ferris, H., Nusbaum, C. J., Griffin, W. E., Small, R. H., and Stone, C. A. 1976. Two semi-automatic elutriators for extracting nematodes and certain fungi from soil. J. Nematol. 8:206-212.

4. Copes, W., Horton, D., Ellis, H. C., Dutcher, J., Yonce, C., Ferree, M. E., MacDonald, G. E., and Sumner, P. E. 1997. Georgia peach integrated crop management guide. Univ. Ga. Coop. Ext. Serv. Misc. Publ. 46.

5. Ferree, M. E., and Meyers, S. C. 1989. Nutrition. Pages 61-69 in: Peach Production Handbook. S. C. Meyers, ed. University of Georgia College of Agriculture, Athens.

6. Jenkins, W. R. 1964. A rapid centrifugalflotation technique for separating nematodes from soil. Plant Dis. Rep. 48:692.

7. Liebl, R. A., and Worsham, D. A. 1983. Inhibition of pitted morning glory (Ipomoea lacunosa L.) and certain other weed species by phytotoxic components of wheat (Triticum aestivum L.) straw. J. Chem. Ecol. 9:10271043.

8. Meyer, J. R., Zehr, E. I., Meagher, R. L., Jr., and Salvo, S. K. 1992. Survival and growth of peach trees and pest populations in orchard plots managed with experimental ground covers. Agric. Ecosyst. Environ. 41:353-363.

9. Miller, R. W. 1994. Estimated peach tree losses 1980 to 1992 in South Carolinacauses and economic impact. Pages 121-127 in: Proc. Stone Fruit Decline Worksh., 6th.

10. Nesmith, W. C., and Dowler, W. M. 1975. Soil fumigation and fall pruning related to peach tree short life. Phytopathology 65:277-280.

11. Nyczepir, A. P., and Bertrand, P. F. 1990. Host suitability of selected small grain and field crops to Criconemella xenoplax. Plant Dis. 74:698-701.

12. Nyczepir, A. P., Bertrand, P. F., and Cunfer, B. M. 1996. Suitability of a wheat-sorghum, double-crop rotation to manage Criconemella xenoplax in peach production. Plant Dis. 80:629-632.

13. Nyczepir, A. P., and Okie, W. R. 1996. Occurrence of peach tree short life on a field site with no history of peach production. Hort- 
Science 31:163.

14. Okie, W. R., Beckman, T. G., Nyczepir, A. P., Reighard, G. L., Newall, W. C., Jr., and Zehr, E. I. 1994. BY-520-9, a peach rootstock for the southeastern United States that increases scion longevity. HortScience 29:705-706.

15. Olien, W. C., Ridley, J. D., Whitwell, T., Watson, W. A., and Newall, W. C. 1994. Methods for establishing nimblewill from seed as a ground cover for peach orchards. Pages 19-23 in: Proc. Stone Fruit Decline
Worksh., 6th.

16. Ritchie, D. F. 1984. Control of Criconemella xenoplax and Meloidogyne incognita and improved peach tree survival following multiple fall applications of fenamiphos. Plant Dis. 68:477-480.

17. U.S. Dep. Agric. 1974. Peach production. Agricultural Handbook No. 463. U.S. Dep. Agric. Agric. Res. Serv., Washington, DC.

18. U.S. Dep. Agric., NASS. 1994. Noncitrus fruits and nuts-1993 Summary. U.S. Dep. Ag- ric., Agric. Statistics Board, Fr Nt 1-3 (94), Washington, DC.

19. Weller, S. C., Skroch, W. A., and Monaco, T. J. 1985. Common bermudagrass (Cynodon dactylon) interference in newly planted peach (Prunus persica) trees. Weed Sci. 33:50-56.

20. Zehr, E. I., and Golden, J. K. 1986. Strip and broadcast treatments of dichloropropene compared for controlling Criconemella xenoplax and short life in a peach orchard. Plant Dis. 70:1064-1066 